\title{
An Empirical Locational Analysis Of The Wheat Flour Milling Industry
}

\author{
Michael W. Babcock*
}

It is generally recognized that the theory of industrial location has evolved along two major themes. One of these major themes is the central place theory as developed by Christaller and Losch with its various modern mathematical adaptations. In general this theoretical approach holds the supply side of the locational calculus constant while focusing primarily on transportation cost and the spatial distribution of demand. It's generally agreed that this theoretical approach most usefully describes the location patterns of the retail trade and service industries whose actual locational considerations closely resemble the assumptions of the central place model.

The other major theoretical approach is the least cost theory which holds demand constant and focuses on spatial variations in cost. It is widely recognized that this theory can usefully describe the location of manufacturing firms, where location is often significantly affected by spatial variation in the prices of a small number of strategic inputs. Economists have relied heavily on the least cost framework in empirical studies of manufacturing location. For examples see [7, Ch. 17 and 18]. This is probably due to (1) the importance of the supply side to manufacturing location and (2) the failure to develop adequate empirical demand models. There have been many empirical applications of the least cost framework to industries where the transportation cost of assembling inputs and distributing outputs is the dominant location factor. Wheat flour milling is a good example of such an industry.

Wheat flour milling is not a labor intensive industry and the labor skills that are required are ubiquitous. Thus labor costs are not an important location factor to the industry. The industry is not a large consumer of energy and therefore not oriented to cheap energy locations. Other operating costs such as interest and taxes likewise have little locational significance. The location pattern of the wheat flour milling industry can best be understood by examining spatial variations in the transportation cost of assembling the major raw material (wheat) and the cost of distributing the output (flour) to markets. Other works that have stressed the importance of transportation costs to the location of this industry include $[1$, pp. $78,344-49 ; 2$, pp. $71-72 ; 3 ; 5$; and 6$]$.

*Department of Economics, Kansas State University. 


\section{Historical Perspective}

Throughout the twentieth century, up until the late 1950's, transportation cost considerations clearly favored a "raw materials" orientation for the wheat flour milling industry. The production process itself is weight losing in nature requiring 1.33 tons of wheat to make 1 ton of flour. The by-products of the production process referred to as millfeed are sold in cattle and chicken feed markets. Since millfeed decays quickly, flour mills that are located close to large livestock populations are able to obtain additional revenues from the sale of millfeed. Mills located in large wheat producing areas have this advantage while those located near the more urbanized eastern parts of the country do not.

The transit rate system provided to the wheat flour milling industry by the railroads also favored the flour mills located in the midwestern wheat belt. The fabrication in transit privilege had the effect of equalizing total transport costs for locations between the major wheat sources and the eastern markets. However, a flour mill transporting wheat from the west could obtain the transit rate only by selling flour to markets east of its location. This had the effect of reducing the size of the market area the farther east the firm located. Thus mills located in the midwest wheat belt were able to sell over a much greater market area and obtain greater economies of scale, though this locational advantage was partly offset by greater population density in the east.

During the first half of this century, the wheat flour milling industry came to be heavily concentrated in the major wheat producing areas of the country, particularly, Kansas, Missouri, and Minnesota in the midwest and Washington and Oregon in the spatially segregated far west market.

\section{The Wheat-Flour Transport Rate Differential}

Prior to the late 1950's, railroads charged identical rates on wheat and flour for similar movements. This was due in part to the desire of the western railroads to attract the industry to western locations and in part to protecting the interests of mills located in either the east or the west. However, in the late 1950's the parity of wheat and flour transport rates was abandoned. Transport rates on wheat were substantially reduced below those of flour. This response by railroads was triggered by substantial competition for wheat traffic from trucks and water carriers.

The Motor Carrier Act of 1935 provided that truck movements of farm commodities would be exempt from rate regulation. The exemption did not apply to grain products such as flour. The full impact of this development was not immediately felt by the railroads. With the development of larger trucks coupled with the substantial improvements in the highway system, the costs of truck transport were substantially reduced.

The opening of the St. Lawrence Seaway in 1959 made it possible to export grain directly from Great Lakes ports, thus bypassing east coast 
ports Faced with this competition for transport of wheat, the railroads substantially lowered wheat rates in order to maintain the volume of their shipments to east coast ports.

The general improvement of inland waterways had the effect of making barge transport of grain competitive with rail transport. Again the response of railroads was to substantially lower the transport rate on wheat relative to flour.

The specific reactions of the railroads to this competition for the transport of wheat includes the famous "Big John" rates enacted by the Southern Railroad. These rates went into effect on May 11, 1963, and applied from St. Louis, Memphis, Evansville, Indiana, Louisville, and Cincinnati, to 37 destinations in the southeast [5, p. 110]. The rates were generally $60 \%$ lower than flour rates for comparable movements [5, p. 112].

On December 2, 1963, the Soo Line Railroad in connection with the Pennsylvania Railroad enacted a unit train wheat tariff from DuluthSuperior and Minneapolis to Buffalo, New York via Chicago [5, p. 131]. The unit train wheat tariff was about $45 \%$ of the flour rate for the same movement [5, p. 132].

In June, 1965, the three major northern transcontinental railroads placed into effect transport rates on export wheat that were nearly $50 \%$ lower than previously identical wheat and flour rates [5, p. 147]. This was done to compete with Canadian railroads for the developing export market in Japan and the Philippines.

In August, 1965, the Southern Railroad enacted a unit train export wheat rate from Louisville to Charleston, South Carolina that was substantially lower than the flour rate for a comparable movement $[5, \mathrm{p}$. 134].

Reductions in wheat export rates from Kansas-Oklahoma origins to Gulf of Mexico ports began in 1957 and have been reduced several times since then. Reductions in wheat export rates in the northwest began in 1958. The railroads enacted substantially lower wheat export rates from northern Idaho, Washington, and Oregon to coastal ports in Washington and Oregon [5, p. 108].

The theoretical locational impact of the sharply lower wheat transport rates on the flour milling industry is clear. In terms of simple Weberian location theory, the locational pull of the market is substantially increased relative to the raw material locations. In the domestic market, flour mills would tend to locate close to large population centers. In the export market, the sharply lower wheat rates would stimulate the construction of foreign flour mills and reduce U.S. exports of wheat flour.

\section{Empirical Analysis}

Table I contains a representative sample of wheat and flour rates from major centers in the wheat producing areas of the country to a sample of major domestic population centers. The rates are current rates (May, 
1977) and tariff references are available on request. In all cases, the wheat rate is substantially below the flour rate for the same movement.

As stated above, prior to 1957 the rail rates for wheat and flour were identical for comparable movements. Since the production process is weight losing, location favored the wheat producing areas. However, the relative locational pulls of the raw material sources and the markets changed substantially with the reduction in the wheat rate relative to flour. In Table II, the relative locational pulls of the market and the raw materials sources are calculated using the wheat and flour rates of Table I.

To compute the relative locational pulls, ideal weights are calculated for the markets and the raw materials sources. The ideal weight for a raw materials source (wheat) is calculated by multiplying the number of tons of input required per ton of output times the transport rate per ton of input (wheat). The ideal weight for the market is simply one ton of output (flour) times the transport rate for flour. 'The relative locational pulls are calculated on the basis of four tons of wheat required to make 3 tons of flour.

An examination of Table II indicates that, in almost every case, the market ideal weight exceeds that of the material source. Thus, we should expect the location of the industry to shift toward the market.

One method of assessing the actual locational impact of the wheat-flour rate differential is an intertemporal comparison of the coefficient of lo-

Table I

Wheat-Flour Transport Rate Differential Comparison (c/cwt)

\begin{tabular}{lcrc}
\hline Origin to Destination & Wheat Rate & Flour Rate & $\begin{array}{c}\text { Wheat Rate/ } \\
\text { Flour Rate }\end{array}$ \\
\hline Kansas City to: & & & \\
Chicago & $27.6^{1}$ & 66.0 & .42 \\
Cleveland & 113.5 & 142.5 & .80 \\
Philadelphia & 163.0 & 187.5 & .87 \\
Detroit & 101.5 & 129.5 & .78 \\
New Orleans & $35.6^{1}$ & 91.0 & .39 \\
Birmingham & 56.5 & 155.5 & .36 \\
Atlanta & 63.8 & 167.0 & .38 \\
Miami & 86.6 & 199.0 & .44 \\
Houston & 57.5 & 91.0 & .63 \\
Minneapolis to: & & & .59 \\
Chicago & $32.5^{1}$ & 55.0 & .50 \\
Detroit & $66.0^{2}$ & 131.5 & .53 \\
Philadelphia & $94.0^{3}$ & 176.5 & .62 \\
New York & $113.5^{4}$ & 183.0 & \\
\hline
\end{tabular}

1Barge rates - 1100 ton minimum charge.

Cleveland, Ohio rate - approximately same distance as Detroit.

3Martins Creek, Pa. rate - Philadelphia suburb.

4 Clifton, N.J. rate - New York suburb. 
Table II

Relative Locational Pull-Markets vs. Raw Material Sources

\begin{tabular}{ccc}
\hline & $(2)$ & \\
$(1)$ & Transport Cost & $(3)$ \\
Weight & Per Ton-Mile & (1) $\times$ (2) $\times 100$ \\
(tons) & $(\phi)$ & Ideal Weight \\
\hline
\end{tabular}

Wheat Source:

Kansas City

\begin{tabular}{|c|c|c|c|c|}
\hline Kansas City & - Chicago & 1.33 & .0126 & 1.68 \\
\hline " & - Cleveland & 1.33 & .0304 & 4.04 \\
\hline " & - Philadelphia & 1.33 & .0269 & $3.5 \varepsilon$ \\
\hline " & - Detroit & 1.33 & .0293 & 3.90 \\
\hline " & - New Orleans & 1.33 & .0082 & 1.09 \\
\hline$"$ & - Birmingham & 1.33 & .0156 & 2.07 \\
\hline$"$ & - Atlanta & 1.33 & .0146 & .9 \\
\hline " & - Miami & 1.33 & .0117 & 1.5 \\
\hline " & - Houston & 1.33 & .0158 & 2.10 \\
\hline
\end{tabular}

Markets:

\begin{tabular}{|c|c|c|c|c|}
\hline Kansas City & - Chicago & 1 & .0302 & 3.02 \\
\hline " & - Cleveland & 1 & .0382 & 3.82 \\
\hline$"$ & - Philadelphia & 1 & .0309 & 3.09 \\
\hline$"$ & - Detroit & 1 & .0373 & 3.73 \\
\hline " & - New Orleans & 1 & .0209 & 2.09 \\
\hline " & - Birmingham & 1 & .0430 & 4.30 \\
\hline$"$ & - Atlanta & 1 & .0383 & 3.83 \\
\hline$"$ & - Miami & 1 & .0268 & 2.68 \\
\hline$"$ & - Houston & 1 & .0258 & 2.58 \\
\hline
\end{tabular}

Wheat Source:

Minneapolis

Minneapolis

$\begin{array}{ll}\text { - Chicago } & 1.33 \\ \text { - Detroit } & 1.33 \\ \text { - Philadelphia } & 1.33 \\ \text { - New York } & 1.33\end{array}$

.0165

.0222

2.19

.0157

2.95

" - Philadelphia 1.33

.0191

2.09

2.54

Markets:

$\begin{array}{cllll}\text { Minneapolis } & \text { - Chicago } & 1 & .0278 & 2.78 \\ \text { " } & \text { - Detroit } & 1 & .0442 & 4.42 \\ \text { " } & \text { - Philadelphia } & 1 & .0296 & 2.96 \\ & \text { - New York } & 1 & .0308 & 3.08\end{array}$

calization. This measure is designed to compare the geographic distribution of production in an industry to its markets. The coefficient is calculated in the following manner:

(1) Compute the percentage distribution of industry production by region.

(2) Compute the percentage distribution of population by region.

(3) Subtract (2) from (1)

(4) Sum the difference obtained in (3) and divide by 100. 
The coefficient can assume values between 0 and 1 . The closer the coefficient is to 0 the greater the market orientation of the industry. In 1963 the coefficient of localization for the wheat flour milling industry (SIC code 20411) was .32. By 1975, the coefficient had decreased to .30 indicating that the industry had become more market oriented. Data was obtained from [10,11, and 12].

Another method of assessing the actual locational impact of the wheatflour rate differential is through a regional shift analysis. This analysis involves the following steps:

(1) Compute the production growth (decline) rate of the national industry over the analysis period.

(2) For each region, compute the production it would have had at the end of the analysis period had the regional industry grown (declined) at the same rate as the national industry.

(3) For each region, subtract (2) from the actual production at the end of the analysis period.

If a region has a positive number in (3) it means that the industry has shifted into the region. Negative numbers indicate the industry has shifted out of the region. A shift analysis was performed for the wheat flour milling industry for the period 1963-1974. Data was obtained from [11]. The analysis clearly revealed a relative locational shift toward the market. The Middle Atlantic states, South Atlantic states, and California all experienced large positive numbers in the shift analysis. On the other hand the wheat belt states of Kansas, Oklahoma, and Texas in the midwest and Oregon and Washington on the west coast experienced negative numbers in the shift analysis. The only exception to the trend toward market location was Minnesota.

Still another way of analyzing the actual locational impact of the wheat-flour transport rate differential is to examine regional changes in wheat flour milling capacity. Table III indicates the net change in the number of wheat flour mills, the net change in total regional flour milling capacity, and the net change in average capacity per wheat flour mill. The changes were computed for all Census regions for the period 19651975. Data was obtained from [8 and 9].

The data in Table III show a national trend toward a smaller number of larger mills. National production has been on a declining trend during the period so the data are consistent with theoretical expectations. That is, central place theory tells us that a decline in demand should lead to a smaller number of firms selling over larger market areas. Also, the widespread adoption of the Airslide railroad car during the period contributed to greater economies of scale in the wheat flour milling industry. The Airslide car substantially reduces the cost of handling and transporting flour. However, it requires substantial investment in rapid loading equipment.

The regional total net capacity changes clearly demonstrate a shift of the industry away from the major wheat producing areas and toward 
Table III

Regional Changes in Wheat Flour Mill Location and Capacity* 1965-1975

\begin{tabular}{lccc}
\hline \multicolumn{1}{c}{ Region } & $\begin{array}{c}\text { Net } \\
\text { Mill Change }\end{array}$ & $\begin{array}{c}\text { Net } \\
\text { Capacity Change }\end{array}$ & $\begin{array}{c}\text { Average } \\
\text { Capacity Change }\end{array}$ \\
\hline Middle Atlantic & -24 & 15481 & 1021 \\
South Atlantic & -43 & 10228 & 791 \\
East North Central & -20 & -690 & 1464 \\
East South Central & -27 & 589 & 828 \\
West North Central & -17 & -17605 & 1352 \\
West South Central & -8 & -12710 & 1389 \\
Mountain & -7 & 19563 & 1584 \\
Pacific & -2 & 3495 & 709 \\
\hline
\end{tabular}

*Capacity is measured in $\mathrm{cwt} /$ day.

major concentrations of population. The Middle and South Atlantic regions both had large net capacity increases while the West North Central and West South Central had large net capacity decreases. On the west coast, the net capacity increase of the Pacific region is the result of net capacity declines in the wheat producing states of Washington and Oregon and a large net capacity increase in California.

There were a few notable exceptions to the trend toward market orientation. Minnesota experienced a large net capacity increase as did the Salt Lake City-Ogden area in Utah.

All of the above analysis clearly indicates that the location of the wheat flour milling industry is shifting toward domestic market centers. But also, given the large wheat-flour export rate differential, we would expect foreign mill construction to be stimulated and U.S. wheat flour exports reduced. Table IV shows the trend of U.S. wheat flour exports 1960-1975. Data was obtained from [4 and 11].

The data in Table IV clearly indicate a continual decline over the entire period of both exports and exports as a percentage of production. Although all this export decline can't be attributed to the wheat-flour export rate differential, it almost certainly made a significant contribution.

\section{Conclusion}

The major conclusion of this paper is that substantial reduction of the wheat transport rate relative to flour has shifted the location of the industry toward the market. The impetus to this change came from the increased intermodal competition for the transport of wheat relative to flour. This situation seems likely to continue for the foreseeable future.

In the Airslide rail car, the railroads have the technology that permits low cost bulk shipments of flour. However in the absence of increased competition for the transport of flour there is little reason to expect these economies to result in lower flour rates. Exemption of truck ship- 
Table IV

U.S. Exports - Wheat Flour

(000 cwt)

\begin{tabular}{lcc}
\hline Year & Exports & Exports/Production \\
\hline 1960 & 43082 & $16.9 \%$ \\
1961 & 43311 & $16.6 \%$ \\
1962 & 47178 & $18.0 \%$ \\
1963 & 44443 & $16.8 \%$ \\
1964 & 42278 & $15.9 \%$ \\
1965 & 30317 & $12.1 \%$ \\
1966 & 33091 & $13.1 \%$ \\
1967 & 21057 & $8.6 \%$ \\
1968 & 28074 & $11.0 \%$ \\
1969 & 26286 & $10.3 \%$ \\
1970 & 26002 & $10.3 \%$ \\
1971 & 20556 & $8.2 \%$ \\
1972 & 20599 & $8.2 \%$ \\
1973 & 16018 & $6.4 \%$ \\
1974 & 14201 & $5.9 \%$ \\
1975 & 11917 & $4.8 \%$ \\
\hline
\end{tabular}

ments of grain products from rate regulation would result in increased competition. However, such exemption does not appear to be imminent. Increased competition by water carriers could force down flour rates. However water carriers do not have the technology to allow low cost bulk shipment of flour. Therefore it seems likely that the location pattern of the wheat flour milling industry will become increasingly market oriented in the future.

\section{Literature Cited}

1. Fair, M. L. and E. W. Williams. Economics of Transportation and Logistics. Dallas: Business Publications Inc., 1975.

2. Locklin, D. P. Economics of Transportation. 7th ed., Homewood: Richard D. Irwin, 1972.

3. Lukerman, F. "The Changing Pattern of Flour Mill Location," Northwestern Miller 261 (1959), pp. 12-14.

4. Miller Publishing Co. The Northwestern Miller, January Issue, 1960-1968.

5. Nightingale, E. A. "Some Effects of Recent Changes in the Railway Grain-Rate Structure on Interregional Competition and Regional Development," Transportation Problems and Policies in the Trans-Missouri West. Edited by J. R. Davidson and H. W. Ottosen. Lincoln: University of Nebraska Press, 1967.

6. Russell, D. J. "Changes in Freight Rate Structure and Their Effects on Grain Pro- cessors," Northwestern Miller, 272 (1965), pp. 22-28.

7. Smith, D. M. Industrial Location. New York: John Wiley \& Sons, 1971.

8. Sosland, M. I. (ed.). "List of U.S. Wheat Flour Mills," Milling and Baking News, 54 (1975), pp. 23-63.

9. Swarbreck, G. E. (ed.). "List of U.S. Wheat Flour Mills," Northwestern Miller, 272 (1965), pp. 22-64.

10. U.S. Bureau of the Census, Current Population Reports, Series P-25, No. 615. Washington, D.C.: U.S. Government Printing Office, 1975.

11. U.S. Department of Commerce. Current Industrial Reports, Flour Milling Products. Washington, D.C.: U.S. Bureau of the Census, 1963-1975.

12. U.S. Department of Commerce. Bureau of the Census, Statistical Abstract of the United States. Washington, D.C.: U.S. Government Printing Office, 1963. 